\title{
Preliminary study on cells viability based on toxicity effect of varnish fluoride made from Indonesian de-waxed shellac
}

\author{
Nina Djustiana ${ }^{1}$, Veni Takarini ${ }^{1 *}$, Zulia Hasratiningsih ${ }^{1}$ \\ 'Department of Dental Materials Science and Technology, Faculty of Dentistry Universitas \\ Padjadjaran, Indonesia
}

\begin{abstract}
Introduction: Varnish fluoride has the ability to prevent enamel demineralization. De-waxed shellac that mostly used for fruits coating, now is applied as varnish fluoride materials. This de-waxed shellac is quite potential since the product can be found from Indonesian sources. The research was aimed to investigate the toxicity effect of varnish fluoride made of de-waxed shellac by measuring the viability of the fibroblast cells. Methods: The research method that was used in this study is in vitro experimental method, which using the tooth that had been smeared with varnish fluoride contacted with fibroblast cells REF (Rat Embryonic Fibroblast) for 4, 8, and 24 hours times. The toxicity effect of varnish fluoride was then measured by cell viability. Results: The results show that the average cells viability on 4 hours contacted tooth was $88 \%$, on 8 hours contacted tooth was $74 \%$, and on 24 hours contacted tooth was $63 \%$ respectively. Conclusion: The conclusion of this preliminary study on cells viability based on toxicity effect of varnish fluoride made from Indonesian de-waxed shellac decreased based on higher contacted time.
\end{abstract}

Keywords: Cell viability, toxicity effect, varnish fluoride, Indonesian de-waxed shellac

p-ISSN: 1979-0201; e-ISSN 2549-6212; Available from: http://jurnal.unpad.ac.id/pjd/article/view/22657

DOI: 10.24198/pjd.vol30no3.22657

Submission: Mar 19, 2019; Accepted: Jul 24, 2019; Published online: Jul 31, 2019

\section{INTRODUCTION}

Enamel is a hard tissue structure on the tooth that can undergo demineralization. One of the cause of demineralization is that lactic acid in oral cavity that can cause dissolution of important calcium in the enamel. This process can be prevented and inhibited by fluoride protection. ${ }^{1}$ The right amount of fluoride consumption can reduce prevalence of caries, but if it excessively consumed shall caused fluorosis. ${ }^{2}$ Topical fluoride is one of the effective fluoride form for direct tooth protection. ${ }^{3,4,5}$ This topical fluoride are available on liquid, paste, gel, and varnish forms. Varnish fluoride has advantages over other forms, because of its ability to bind with the tooth surface and resulting in fluoride contact with tooth structure two times longer than fluoride in toothpaste and gel forms and also its ability to reduce demineralization. ${ }^{6,7}$

Shellac is usually used as a coating agent on variety food and fruits, and one of the safe shellac that are used in pharmaceutical application is de-waxed shellac. ${ }^{8}$ De-waxed shellac is used as a protective layer (excipients) 
in tablets and capsules by the Pharmaceutical \& Nutritional Supplement industry. It is recognized as safe as non-parenteral medicines (tablets and oral capsules) licensed from the UK, and also Food and Drug Administration (FDA) Inactive Ingredients Database in the United States. ${ }^{9}$ The natural de-waxed shellac also can be found from Indonesian sources and this potential is utilized as self-synthesized varnish fluoride formulation to prevent enamel demineralization by smeared it to tooth structure.

Varnish fluoride can be categorised as foreign substances, which applied to tooth structure in some period of time. This foreign substances made from Indonesian de-waxed shellac needs to be investigated its toxicity effect before it can be applied to the patient. Toxicity effect can be studied using the percentage of living cells in the sample, which is called cell viability that really fundamental during biology studies. Fibroblast cell is the type of cell that is used in this research, which is the most stroma cell that form mucosa tissue in oral cavity. ${ }^{10}$ The preliminary research was aimed to describe the toxicity effect of varnish fluoride made of de-waxed shellac by measuring the viability of the fibroblast cells.

\section{METHODS}

The research method was quasi experimental with in vitro test to find the effect of varnish fluoride's toxicity towards the fibroblast cells culture, which was the Rat Embryonic Fibroblast (REF). Research was conducted at the Culture and Cytogenetic Laboratorium of Hasan Sadikin General Hospital. First, samples of premolar teeth were applied with self-synthesises Indonesian de-waxed shellac varnish fluoride on its surface. Second, all samples were sterilized in the laminar airflow cabinet for 30 minutes in the top and bottom surfaces respectively. The sterilised samples were then transferred using the stainless steel tweezers to the REF cell culture on 9 plate wells. The samples were then incubated and the media solution was then rinsed with buffer saline. Third, cells were released from 9 plate wells by added $1 \mathrm{ml}$ versin trypsin then vibrated for a minute. After being centrifuged, the samples were then added with tryphane blue and complete culture medium. Lastly, dripped it to hemocytometer, then the samples were ready to be seen under the microscope. Sampling method was using minimal sampling with duplo method, with twice repetitions. The tooth that had been applied with varnish fluoride then contacted with fibroblast cells REF (Rat Embryonic Fibroblast) for 4, 8, and 24 hours times. The ethical clearance statements for the research were based on Reg. No. 0818010027 from Ethical Commission of Faculty of Medicine Universitas Padjadjaran.

\section{RESULTS}

The results of this study are shown from mean of cells viability that presented on the table and described on the pictures from the microscope.

Table 1. Cells viability based on toxicity effect of varnish fluoride made from Indonesian de-waxed shellac

\begin{tabular}{|c|c|c|c|c|c|c|c|c|c|}
\hline \multirow{2}{*}{ Repetition } & \multicolumn{3}{|c|}{4 hours (P1 and $P 2)$} & \multicolumn{3}{|c|}{8 hours (P3 and P4) } & \multicolumn{3}{|c|}{24 hours (P5 and P6) } \\
\hline & Living Cells & Dead Cells & Viability & $\begin{array}{l}\text { Living } \\
\text { Cells }\end{array}$ & Dead Cells & Viability & $\begin{array}{l}\text { Living } \\
\text { Cells }\end{array}$ & Dead Cells & Viability \\
\hline 1 & 12 & 0 & $100 \%$ & 8 & 3 & $73 \%$ & 3 & 2 & $60 \%$ \\
\hline 2 & 6 & 2 & $75 \%$ & 6 & 2 & $75 \%$ & 4 & 2 & $67 \%$ \\
\hline Mean & 9 & 1 & $88 \%$ & 7 & 2.5 & $74 \%$ & 3.5 & 2 & $63 \%$ \\
\hline
\end{tabular}

Table 1 shows that viability of REF cells are decreasing based on the longer time. The mean of cells viability on 4 hours contacted tooth is $88 \%$, while the mean on 8 hours was $74 \%$, and the mean on 24 hours contacted time was $63 \%$. The figures 1,2 , and 3 show fibroblast and fibrocytes that can be counted as the cells viability.
Fibroblast cells resembles mesenchymal cells in structural form, which are stellate with a long, large cytoplasmic process, ovoid, and pale nucleus. This type of fibroblast cell plays an important role in producing collagen and other matrix components (tissue regeneration). Whereas, apoptotic fibroblast cells have their extracellular 


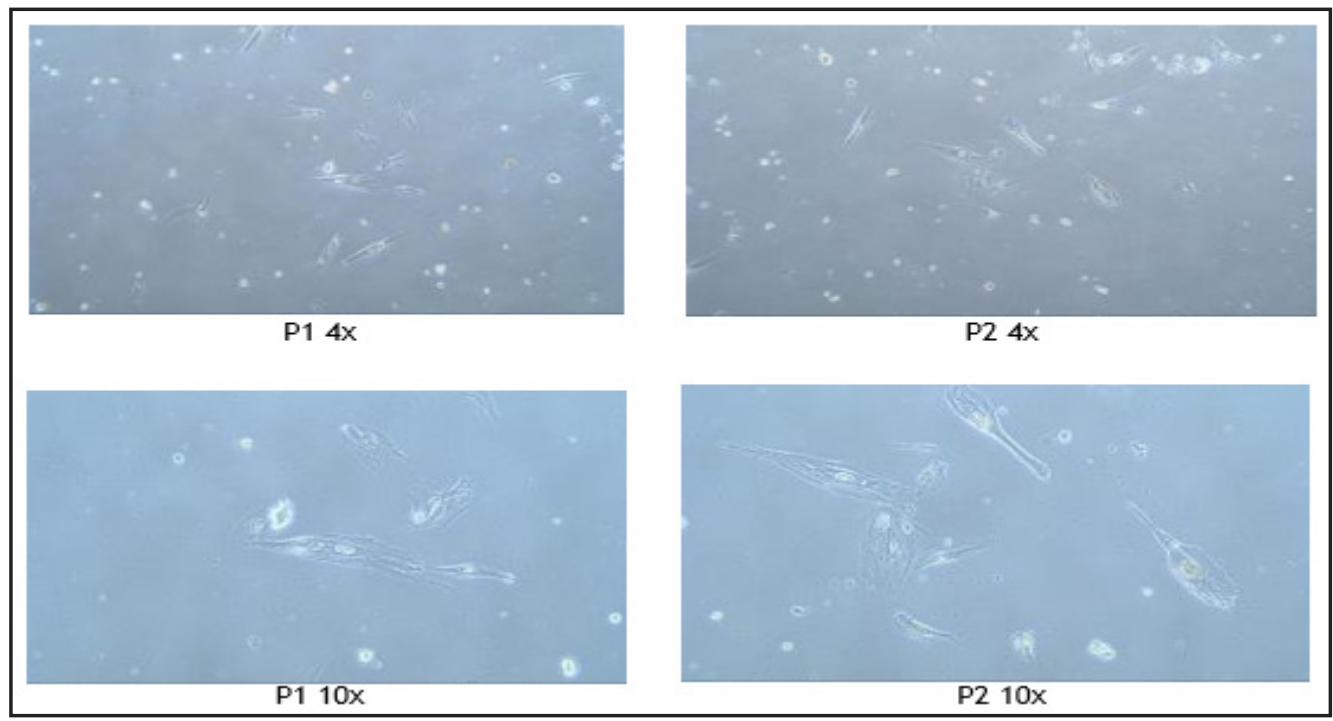

Figure 1. Cells viability on 4 hours contacted tooth with 4 and 10 times magnification

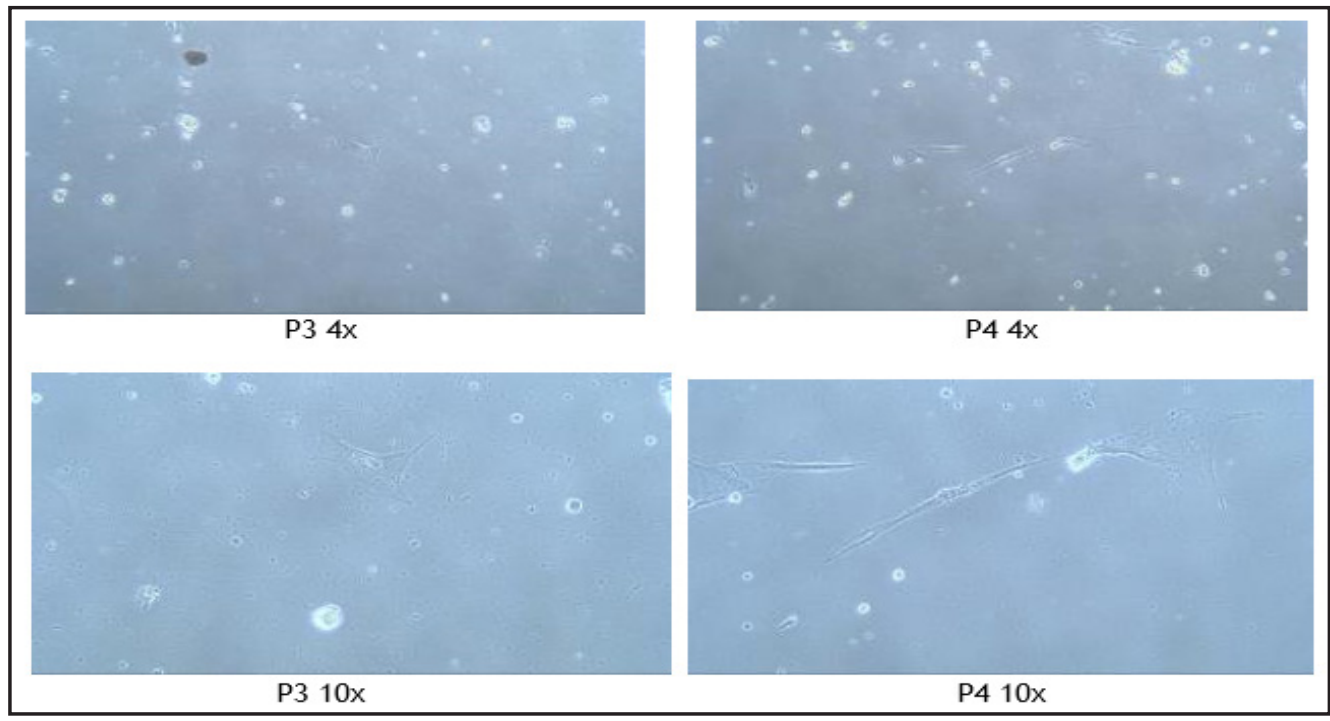

Figure 2. Cells viability on 8 hours contacted tooth with 4 and 10 times magnification

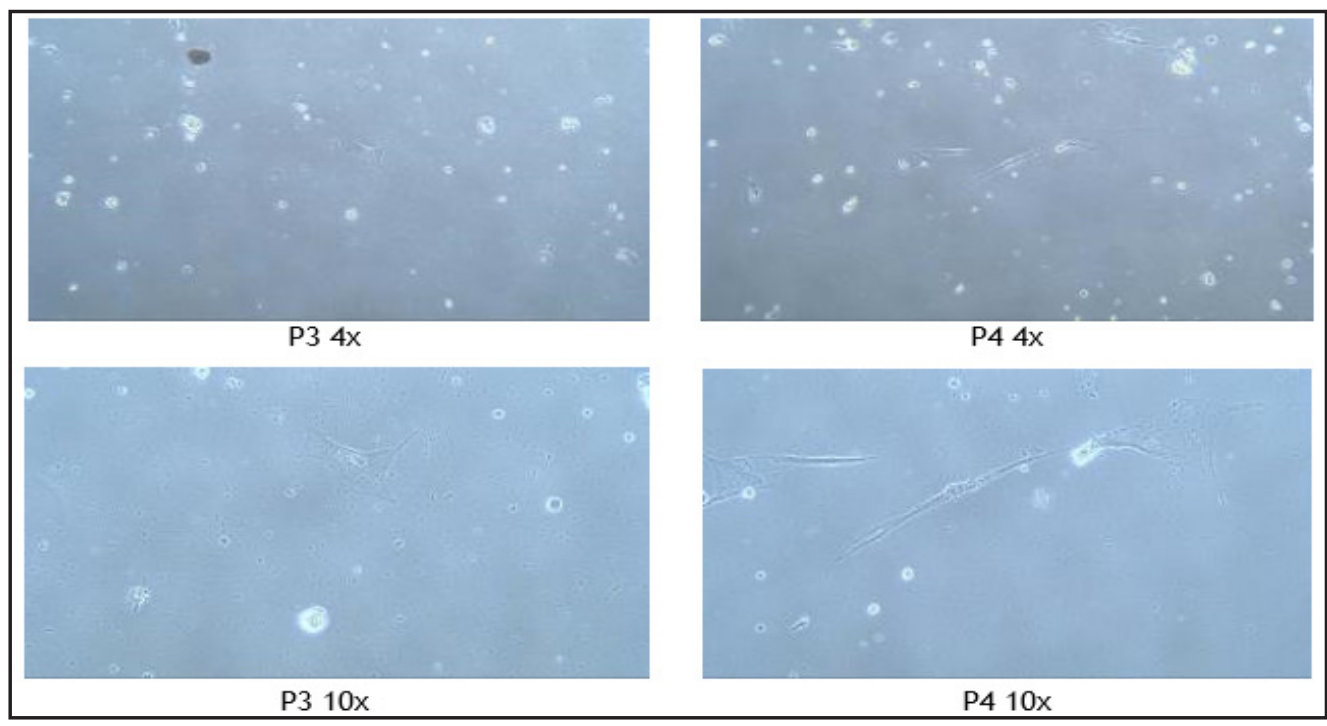

Figure 3. Cells viability on 24 hours contacted tooth with 4 and 10 times magnification 
membrane destroyed, seen as necrotic cells in culture since there's no phagocytosis occur. Necrotic cells (apoptotic fibroblast cells) show oncosis, broken membrane plasma, and losing its intracellular components. ${ }^{11-15}$

\section{DISCUSSION}

Fluoride is market available in systemic and topical forms. The topical fluoride form can prevent demineralization more effectively, and one of the topical fluoride forms is available as fluoride varnish. ${ }^{16,17}$ Fluoride varnish is a material that attaches to the surface of teeth, has yellow colour, semi-liquid, contains resin fluoride and contains alcohol, which can speed up the drying process. ${ }^{17}$ Varnish fluoride contain of $5 \%$ active sodium fluoride ingredient $(22,600 \mu \mathrm{g} F / \mathrm{g})$ or $1 \%$ difluorosilane (1000 ppm). . $^{2,18}$

Varnish fluoride also has the ability to bind to the tooth structure, so that it can be firmly attached and also shall produce fluoride two times longer than fluoride in toothpaste and gel. This fluoride production would happen not only while contact with teeth, but also will benefit on reduces demineralization. ${ }^{6,7}$ The fluoride content is known to be effective in protecting tooth enamel, because its ability to diffuse into enamel can form fluoroapatite, which initiates the re-mineralization process and can destroy acid production from bacteria. Fluoride varnish is only used in small amounts when applying, $0.5 \mathrm{ml}$ of varnish that can be given to children. ${ }^{17}$ Usually it is important that the fluoride varnish remains on the teeth for the rest of the day and overnight to provide the best possible benefit. ${ }^{19}$ But, this material will also be easily to disappear along with the tongue, cheeks, and labial scrape due to its eating habit and also lack of mechanical strength. One type of shellac that is safe to use in pharmaceutical applications is de-waxed shellac. In previous studies, Indonesian de-waxed shellac based fluoride varnish has the ability to prevent enamel demineralization, but dental material must be non-toxic and have adequate biocompatibility. ${ }^{20}$

In order to count the cell viability, it can be identified based on the fibroblast and fibrocytes cells. The fibroblasts can be seen in soft connective tissues as predominant stromal cell and appear as plump spindle shaped or stellate shaped cells (active fibroblasts) with round or oval nucleus. Their role are maintaining the structural integrity of connective tissues in health, healing processes, and in pathological alterations. Fibroblast can act as architects and caretakers of connective tissues, and its variants can be seen both within a localized site (e.g. gingiva) and also between sites from various locations. ${ }^{21}$ In the past few years it has been discussed that fibroblasts/ myofibroblasts, which participate in repair and fibrosis, not only have their origin in the fibroblasts already present in the injured tissues but also may derive from other sources, such as mesenchymal and hematopoietic stem cells, as well as from epithelial-mesenchymal transition. ${ }^{12,13}$

If there is a wound, then fibroblast are really considered essential in the healing process that originating from peripheral blood cells. The term fibrocytes was started to describe in 1994 as a distinct population of blood-borne fibroblastlike cells that rapidly enter sites of tissue injury. ${ }^{22}$ These cells comprise $0.1-0.5 \%$ of nonerythrocytic cells in peripheral blood and show an adherent, spindle-shaped morphology. Fibrocytes express collagen and fibronectin. Morphology, growth properties and cell surface markers of fibrocytes appear to be distinct from monocytes/ macrophages, dendritic cells, and other antigen presenting cell types. ${ }^{23}$ Based on their presence in wounds and their secretion of proinflammatory cytokines, chemokines, and extracellular matrix proteins, fibrocytes have been postulated to play a role in connective tissue formation in wound healing. ${ }^{21}$

Cell viability can be known by count the living cells divided by total cells on hemocytometer. Living cells couldn't absorb the color of tryphane blue because it is unable to penetrate the membrane cell. Kromer ${ }^{14}$ and Nguyen ${ }^{15}$ found that dead cells have their membrane's defected then can absorb the color of tryphane blue, so the cells could be seen as blue color cells under microscope. Dead cells can be seen as bulging, defected membrane cell, and losing its intracellular components. ${ }^{14,15}$

The recommended dose of varnish fluoride that applied for over 6 years age children is usually at $0.4 \mathrm{ml}$, while the correct dose for children with deciduous teeth is $0.25 \mathrm{ml}$. This $0.25 \mathrm{ml}$ is the same level in containing $5.6 \mathrm{mg}$ of 
fluoride-well within safe levels. ${ }^{19}$ These dose are not contradictory of the research, which applied varnish fluoride using Indonesian de-waxed shellac twice using an applicator on premolar teeth that this are still in its safety margin since most of the adult teeth were already calcified. The application of fluoride varnish relies on the topical action of fluoride although inevitably a little of the varnish will be swallowed.

Achild usually should receive fluoride varnish four times a year, which is still within the safe limits for either acute toxicity levels or chronic ingestion resulting in fluorosis. For the toxic dose is estimated as fluoride ingestion at $5 \mathrm{mg}$ per $\mathrm{kg}$ of child body weight as the average of three year old weighs of $11-20 \mathrm{~kg}$. The absorption of fluoride is really quick on the stomach and an acute toxicity can be caused also by small amounts of fluoride in taking. This can cause nausea, vomiting, and stomach irritation, while at a very high amount can cause serious systemic symptoms and toxic signs, also the possibility of death. ${ }^{19}$

Sakaguchi ${ }^{2}$ and Anusavice ${ }^{24}$ stated that dental materials should have biocompatibility property on its applications to prevent tissue irritation and cytotoxicity. ${ }^{2,3}$ Biocompatibility could be known by toxicity tests, one of them is using in vitro method to inspect the cells' viability towards the dental material. Parameter to inspect the cytotoxicity is Cell Death50 (CD50). The dental materials could be determined as toxic, if the viability cells after having contact with the materials is under $50 \%$. Materials are have good biocompatibility, if its cells viability is in between $92.3-100 \%$, but can not be determined on this research since this is still preliminary study. ${ }^{2,24}$

\section{CONCLUSION}

The conclusion of this preliminary study on cells viability based on toxicity effect of varnish fluoride made from Indonesian de-waxed shellac decreased based on higher contacted time.

\section{ACKNOWLEDGMENT}

This research is funded by Ministry of Research and Higher Education based on SIMLITABMAS Research.

\section{REFFERENCES}

1. Sbaraini A, Evans RW, Kleinberg I, Featherstone JDB, Ribeiro AA, Carolina N, et al. Dental caries: A dynamic disease process. Aust Dent J [Internet]. 2016;53(4):369-77. Available from: http://www.columbia.edu/itc/hs/medical/ pathophys/id/2006/DentalCaries.pdf.

2. Sakaguchi RL, Powers JM. Restorative Materials-Ceramics [Internet]. Craig's Restorative Dental Materials. 2012. 253-275 p. Available from: http://linkinghub.elsevier. com/retrieve/pii/B9780323081085100118.

3. Zhang Y-R, Du W, Zhou X-D, Yu H-Y. Review of research on the mechanical properties of the human tooth. Int J Oral Sci [Internet]. 2014;6(2):61-9. Available from: http://www. nature.com/doifinder/10.1038/ijos.2014.21.

4. Neel R, Kenrick DT, White AE, Neuberg SL. Individual differences in fundamental social motives. J Pers Soc Psychol. 2016;110(6):887907.

5. Ingle, John; Bakland, Leif; Baumgartner JC. This ebook is uploaded by dentalebooks.com. 2008.

6. VicenteA, RuizAJO, Paz BMG, Loâpez JG, BravoGonzaâlez LA. Efficacy of fluoride varnishes for preventing enamel demineralization after interproximal enamel reduction. Qualitative and quantitative evaluation. PLOS One. 2017;12(4):1-11.

7. Li X, Wang J, Joiner A, Chang J. The remineralisation of enamel: A review of the literature. J Dent [Internet]. 2014;42:S12-20. Available from: http://dx.doi.org/10.1016/ S0300-5712(14)50003-6.

8. Farag Y. Characterization of different shellac types and development of shellac coated dosage forms, Dissertation. 2010; Available from: http://ediss.sub.uni-hamburg.de/ volltexte/2010/4814/

9. A. F. suter \& Co. Ltd. Pharmaceuticals \& Nutritional Supplements. industry [Internet]. 2016; Available from: https://www.afsuter. com/industry/pharmaceuticals-nutritionalsupplements/.

10. Stoddart MJ. Mammalian cell viability. Clifton: Humana Press; 2011. 
11. Eroschenko, Victor P. 2005. diFiore Atlas of Histology with Functional Correlations. 11th ed. Moscow:Lippincott Williams \& Walkins.

12. Hinz B, Phan SH, Thannickal VJ, Galli A, Bochaton-Piallat ML, Gabbiani G. The myofibroblast: one function, multiple origins. Am J Pathol 2007;170:1807-1816.

13. Garcia de Alba C, Becerril C, Ruiz V, Gonzalez Y, Reyes S, Alvarez JG, Selman M, Pardo A. Expression of Matrix Metalloproteases by Fibrocytes Possible Role in Migration and Homing. American J of Res and Critical Care Med, 2010; 182(9).

14. Wong MCM, Clarkson J, Glenny AM, Lo ECM, Marinho VCC, Tsang BWK, et al. Cochrane reviews on the benefits/risks of fluoride toothpastes. J Dent Res. 2011;90(5):573-9.

15. Methodist U, Fund HM. Oral Health. 2004; Available from: http://www.kdheks.gov/ohi/ download/Fluoride_Varnish_Insert_Final.pdf.

16. Carey CM, Coleman SS. Method for the analysis of total fluoride in fluoride-releasing dental varnishes. Caries Res. 2014;48(4):306-11.

17. Hasirci V, Yucel D. Encyclopedia of Biomaterials and Biomedical Engineering. Encycl Biomater Biomed Eng. 2007.
18. Ravikanth $M$, Soujanya $P$, Manjunath K, Saraswathi TR, Ramachandran CR, Heterogenecity of fibroblasts, J Oral Maxillofac Pathol. 2011 May-Aug; 15(2): 247-250.

19. Bucala R, Spiegel LA, Chesney J, Hogan M, Cerami A. Circulating fibrocytes define a new leukocyte subpopulation that mediates tissue repair. Mol Med. 1994;1:71-81.

20. Abe R, Donnelly SC, Peng T, Bucala R, Metz CN. Peripheral blood fibrocytes: Differentiation pathway and migration to wound sites. J Immunol. 2001;166:7556-62.

21. Kroemer, G., dkk. "Classification of cell death: recommendations of the Nomenclature Committee on Cell Death". 2009. Cell Death Differ, Vol 16(1):3-11.

22. Nguyen, Long Giang. Cytotoxicity of Eluates from Denture Base Materials. Tesis. Universitetet I Bergen, 2015.

23. National Health Service. Childsmile and fluoride varnish. Available from:http://www. child-smile.org.uk/professionals/aboutchildsmile/childsmile-and-fluoride-varnish. aspx

24. Anusavice, Kenneth J. Phillip's Science of Dental Materials. 12th ed. Missouri:Saunders, 2013. 